\title{
FURNACES: VISIONS OF THE AMERICAN DREAM AND NigHTMARE IN BRADDOCK
}

John C. Spurlock, Seton Hill University, spurlock@setonhill.edu

DOI: $10.31902 /$ fll.31.2020.6

UDK: 821.111(73).09-31

\begin{abstract}
Two works of fiction, one a novel, the other a movie, provide a harrowing journey from the American Dream to the American nightmare. Appearing about 70 years apart, Out of this Furnace (by Thomas Bell) and Out of the Furnace (directed by Scott Cooper) closely examine the lives of steelworking families in Braddock, Pennsylvania. The novel shows the hopes and aspirations of Slovak immigrants slowly improving their material lot over three generations. The movie fast forwards through two more generations to show Braddock in terminal decline, a victim of deindustrialization and all the social ills of America's economic inequality. Taken together these works reveal the arc of American economic development in the 20th century as experienced in the lives of those who experienced it most directly.
\end{abstract}

Keywords: steel mill, steelworkers, working class, violence, American dream, deindustrialization, economic mobility, Braddock, Slovak, immigration, assimilation

Out of this Furnace is Thomas Bell's 1941 novel of Slovak immigrants struggling to make better lives for themselves in the early 20th-century steel mills and milltowns of the Monongahela Valley near Pittsburgh. More than 70 years later, in 2012, Scott Cooper directed Out of the Furnace, a gritty action movie, but also a portrait of America's struggling and declining working class. These two works have no characters in common, no plot lines or narrative threads that are the least similar. Yet along with titles that are almost identical, the stories take the same place as their setting, have the same steel mill as a backdrop, and drill into the lives, hopes, and despairs of America's industrial working class. Together they bookend one of the key developments of American life. Bell shows, in moving prose, the core of the American dream, the meaning of becoming truly American; Scott Cooper unleashes both the characters and imaginary of the American nightmare. Taken together, these works offer a fictional biography of an American industry and of the American working class.

Out of this Furnace is the story of a family and of a place. In 1881 George Kracha leaves his village in the kingdom of Hungary for 
America, hoping also to leave "behind the endless poverty and oppression which were the birthrights of a Slovak peasant in Franz Josef's empire" (Bell, 3). Kracha becomes an unskilled steelworker, first in Homestead and then in Braddock. He remains illiterate, never learns much English, and like Slovak peasants in the old country, "fears authority in whatever guise" and practices "patience and humility and patience" in the face of the contempt of his Anglo and Irish American co-workers. Kracha and his friends suffer no illusions about their treatment or position in the hierarchy of American workers. As an immigrant priest from eastern Europe said of his parishioners, "My people are not in America, they are under it" (Jacobson, 72). But Kracha, and others who immigrated with him, already recognize that their future is in America. His friend Dubik says early in the book, "my children will be Americans, real Americans" (Bell, 34).

A younger immigrant, Mike Dobrejcak, who marries Kracha's daughter, makes greater progress toward gaining an American identity. "You a citizen?" asks one of the company's managers who had shown up to hand out ballots to Mike's work group, pre-marked for the Republican candidates. The only Slovak in his team, Mike always got the same question. Yes, Mike was a citizen, and he'd taken night classes to learn to read English and to gain some sense of the history of his new home. And, in spite of his fear that somehow the company would find out, he ignores the company's chosen candidates and votes for the socialist ticket (Bell, 188-9).

Mike's son, John (everyone calls him Dobie) becomes a skilled laborer and eventually a leader in the union. With Dobie, we see the realization of the American dream for these Slovak immigrants. He becomes not just a union leader, but also a fully assimilated American. Before, he reflected, "saying you were an American satisfied no one where did your father come from?" always followed any new acquaintance. But working with others in the union, many, like him, the children of immigrants, he realized that all of them thought and talked like Americans. "If I'm anything at all I'm an American only I'm not the kind you read about in history books or that they make speeches about on the Fourth of July; anyway, not yet" (Bell, 409). With Dobie, we see the product suggested in the title - Americans created in the furnace of American life, a literal and figurative melting pot.

The timeframe of the movie is far more compressed than the book. Rather than three generations, it covers only five years, from 2008 to 2012. Most of those years the protagonist, Russell Baze, spends in prison for a drunk driving accident, a period covered in a few brief scenes. The family saga is also compressed. The many family 
members and friends of Kracha and his descendents resolve into the Baze family. Russell lives with his critically ill father. Russell's brother Rodney also lives with them. He has returned from service in Iraq with demons that only more violence keep in check. The next generation, the child that Russell wants to have with his lover, Lena, is never conceived, as Lena drifts into marriage with the police chief of Braddock during Russell's prison time. Later in the movie we see Russell working on his father's home, making improvements to the windows and painting the exterior. But his struggle to sustain his family proves futile. His father dies while he serves his time in prison, and Rodney falls further into debt and violence (Dargis).

Russell's father would have been about the age of the son born to Mike Dobrejcak as the book concludes. As the son of a skilled worker and union official, he would have begun his work life in the mill by the end of high school, if not before, and moved readily into an apprenticeship. Post World War II American steel dominated the world's market, and the growing strength of the United Steel Workers (USW) insured that union members received ever better wages and benefits from the industry. In his life, Russell's father would have lived through the dominance of both US Steel and the USW, and also the slow slide that set in for both industry and union after the 1960s. As one plant after another closed in the Monongahela Valley, the region was left with vacant properties, shrinking towns, blasted hopes, and bitterness (Serrin).

While we have to take a little poetic liberty to imagine a connection between the two families in these works, the setting for these stories is a real place. Even a casual visit to today's Braddock reveals signs of a roaring industrial past and a long period of decline. But the same visitor could readily imagine today's Braddock as the place depicted in Thomas Bell's novel of a century ago. The steel mill, the Edgar Thompson Works, bulks as large today as in 1910, separating Braddock from the Monongahela river. Kracha's first minutes in Braddock offers a description that could have applied to any of the milltowns on the Mon. His friend's wife led him and his family

across the tracks and down into dark, badly lit streets lined with houses that looked old and shabby even at night. Children played under corner gas lamps; older people were vague, murmuring shadows on doorsteps and porches [...] the evening was stuffy and windless, the air so acrid with smoke that even Kracha coughed. 
Kracha asks where the mill is, and Francka points down the hill. "There was little to see. At the far end of the street were a few purplish arc lights, a dim bulk, and above and beyond it a flickering yellow glow that made lazily-moving shadows of smoke and steam" (Bell, 25). The Mon Valley would stand for decades as the heart of American industrial growth and also as an illustration of everything bad and dangerous about industrialization. The air there was so thick with pollution that clothing hung to dry would be covered with grit and ash. Even healthy men and women became subject to fits of coughing and weakened lungs that could lead to diseases like leukemia that eventually claims Kracha's daughter. As reformer Lincoln Steffens wrote at the turn of the last century, "Pittsburgh is hell with the lid off" (Steffens).

If Braddock and the other mill towns are not quite hell, in Bell's novel they represent a kind of purgatory, a punishing interlude on the way to something better. "Immigrants continued to pour into the valley," Bell writes, "taking over whole sections - invariably the worst sections, nearest the river and the mills - of the steel town" (Bell, 122). As they gained some seniority in the mills, earned enough for better housing, they moved further from the rancid river and the mill. Social mobility meant literally moving up the embankment, nearer to the spacious homes of the mill's Anglo-American managers. Later in the book Dobie walks up the streets in Braddock.

As he climbed the town flattened, fell away, to his left. There was a blur of heat and smoke above the rooftops which grew thicker with distance; toward Rankin and Homestead it was an impenetrable discoloration against the sky. As a child playing in Washington Street Dobie had believed that was where the world ended. (Bell, 299)

The hope offered in Bell's Furnace is that the world does not end at the Braddock line or even at the margin of the Mon Valley. For Bell's Slovak immigrants, Braddock becomes the way station to a much larger world available to them as Americans. The Mon Valley is the forge of that American identity.

Where the Braddock of Bell's novel shows us a hellish landscape slowly domesticated by hard work and family ties, the Braddock of Scott Cooper's movie is a small town unraveling. Early in the movie, after Russell leaves his shift at the mill, he drives through streets of empty and burned out houses. The liveliest place he finds is the off track betting shop where his brother Rodney is losing more money borrowed from a local bar owner. If anything, though, Cooper's 
cinematic Braddock looked better than the reality when the movie was shot. The movie town has a stable population, with children attending school and low-paying work available for those who care to find it. The police force functions. In reality, Braddock by 2012 was functionally a ghost town, with only 10 percent of its peak population. Even the grim scenes in the Cooper movie do not adequately portray the "ravaged, near-empty stretch of abandoned homes, storefronts, and buildings" (Straub and Liebendorfer). The depressing, if not devastated, cityscape that Cooper portrays has more attractive features than Bell's hellscape of pollution and endless toil. Yet behind the facade or normal life in Cooper's movie is a reality of violence, trauma, and death (Serrin).

Thomas Bell, in his novel, never portrays the steel mill with romantic nostalgia. The mill pollutes the air and the river, stunts the growth of children who live nearby, and kills at least three people named in the book. Millworkers can only hang on to youth until about age 30. After that, their evenings are given to quiet nights at home. The women who care for the household and take in borders work too, and if anything, harder than the men do. The mill's power is fearsome and ugly, but it also provides work for the immigrant families. When the mill slows, so does work, and life becomes more precarious. But in the movie, the mill only plays the role of declining. This mill grinds away slowly at life. "The mill killed our father," Rodney says at one point. Violence seems to live only outside the mill, in bare knuckle prize fights, drug addiction, and murders. In the third act we learn that the mill is closing soon. "Cheaper to get the steel from China," Russell says, words repeated all over the Mon Valley and around the U.S. in the early 21st century.

If we extend the fantasy that these two works are connected through the Dobrejcak/Baze family, then we see that it takes three generations for Slovak peasants to attain the top ranks of the American working class. And then, only two more generations for them to live through the decline of their industry and union. These two works bookend one of the stories of the American working class. Bell's realism never abandons his characters to nameless forces. He shows how the hard work and dreams of immigrants slowly yielded better lives and hope for even more improvement. Powerful forces in the environment and society shape their lives, but never overwhelm them. In Scott Cooper's movie, the gritty realism of his genre ultimately sees his characters overwhelmed by violence. Political and economic forces far beyond Braddock continuously strip away parts of the lives that Russell and Rodney can hope for. Their patriotism and hard work only 
just barely keep at bay the criminal violence fueled by drugs and gambling. One moment of ill fortune leaves them at the mercy of all worst things in their world. Braddock, its mill closing, is no longer hell with the lid off. It's just hell.

\section{Works Cited:}

Alexander, June Granatir. "Out of This Furnace." Journal Of American Ethnic History, vol. 10, 1990, pp. 137-39.

Bell, Thomas. Out of This Furnace. University of Pittsburgh Press, 1976. Dargis, Manhola. "Fraternal Ties, of Gut and Sinew 'Out of the Furnace,' With Christian Bale." New York Times, 3 Dec. 2013, http://www.nytimes.com/2013/12/04/movies/out-of-thefurnace-with-christian-bale.html.

Dillingham, William Paul, and United States Immigration Commission. Reports of the Immigration Commission: Dictionary of Races of Peoples. Government printing office, 1910.

Goldberg, David J. "Thomas Bell's Out of This Furnace: An Evaluation and an Appreciation." Journal Of American Ethnic History, vol. 29, 2010, pp. 62-66.

Hine, Lewis. Steelworkers at Russian Boarding House, Homestead, PA. 1908 1907, https://commons.wikimedia.org/wiki/File:Steelworkers_at_Ru ssian_Boarding_House_Homestead_Pennsylvania_by_Lewis_Hi ne.jpeg.

Jacobson, Matthew Frye. Barbarian Virtues: The United States Encounters Foreign Peoples at Home and Abroad, 1876-1917. Hill and Wang, 2001.

Serrin, William. Homestead: The Glory and Tragedy of an American Steel Town. 1st ed, Times Books, 1992.

Staub, Jim, and Bret Liebendorfer. "Braddock Pennsylvania Out of the Furance and into the Fire." Monthly Review, vol. 60, Dec. 2008, https://monthlyreview.org/2008/12/01/braddockpennsylvania-out-of-the-furnace-and-into-thefire/\#lightbox/0/.

Steffens, Lincoln. The Shame of the Cities. Gutenberg Project EBook, 2017, https://www.gutenberg.org/files/54710/54710-h/54710h.htm\#Page_147.

Wallace, Margaret. "'Out of This Furnace' and Other Recent Works of Fiction." New York Times, 6 Apr. 1941. 


\section{LOS HORNOS: VISIONES DEL SUEÑO AMERICANO Y LA PESADILLA AMERICANA EN BRADDOCK}

Dos obras de ficción, una novela y una película, ofrecen un viaje desgarrador desde el sueño americano a la pesadilla americana. Con 70 años de diferencia, Out of this Furnace (por Thomas Bell) y Out of the Furnace (dir. Scott Cooper) examinan con detalle las vidas de las familias acereras de Braddock, Pennsilvania. La novela revela las esperanzas de los inmigrantes eslovacos que paulatinamente, en tres generaciones, van mejorando su nivel económico. La película avanza dos generaciones más para mostrar Braddock en completo declive, víctima de la desindustrialización y todos los males sociales de la desigualdad económica estadounidense. En conjunto, estas dos obras revelan el trasfondo del desarrollo económico americano del siglo $\mathrm{XX}$, con las experiencias vitales de aquellos que lo experimentaron más de cerca.

Parablas clave: planta siderúrgica, acerero, clase obrera, violencia, sueño americano, desindustrialización, movilidad, económica, Braddock, Eslovaco, inmigración, asimilación. 